\title{
LETTER:
}

\section{FERDO LUPŠA (1882-1945) - ONE OF THE FIRST WESTERN RESEARCHERS OF CAVES IN THAILAND}

\section{Andrej KRANJC}

UDK 929Lupša F.:551.44(593)

Ferdo (Ferdinand) Lupša was born in a small village Drakovci, near the town of Ljutomer, in the North-western part of the nowadays Slovenia, in those times in Austro-Hungarian Empire. Upon concluding his studies, he became an engineer of geodesy. During his stay in Vienna, when he tried to persuade government to finance a polar expedition, he met Lange, a consul of Kingdom of Siam

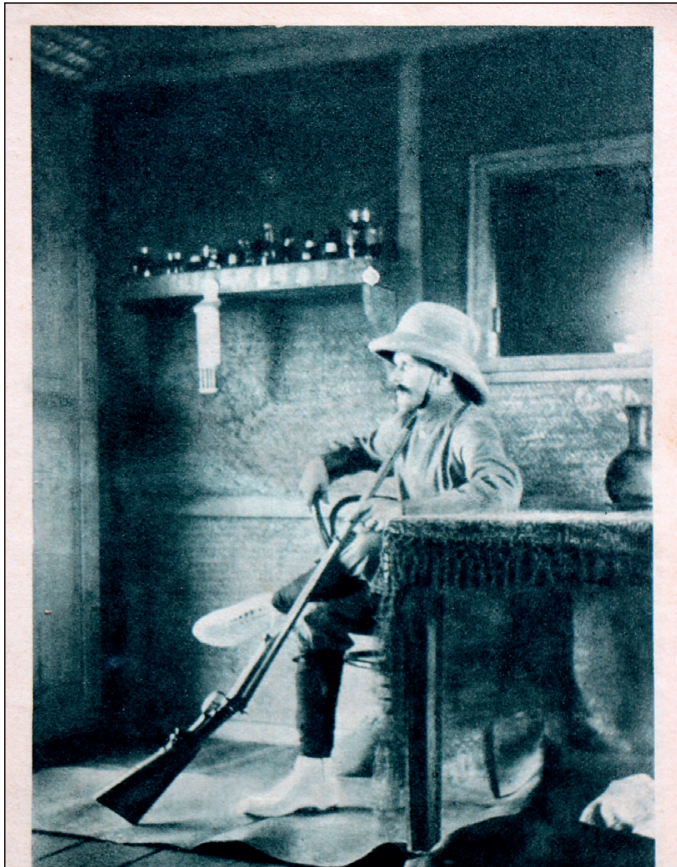

Ferdo Lupša in Siam (Lupša 1930). (now Thailand). The consul advised him to visit Siam. Six months later he visited Vienna again to sign the contract with "Siam Canals Land and Irrigation Company". The contract obliged Lupša to stay for six months in Siam to study various places and environmental conditions.

On February 29, 1904 he went to Italian port of Génova by train and embarked German steamer Prinz Heinrich. He travelled via Naples, Port Said and Suez to the Red Sea. In May of the same year he reported from Siam already. In his letter to the journal Domovina he complained that he needs three days to reach the post office at Klong-Rangait (Rangsit Klong) and has access to it every two weeks only (Lupša 1904a; Lupša 1904b).
He became an engineer at the Royal Irrigation Department, and the owner of a relatively large land plot (Lupša 1906). In the second half of 1906 he returned home. The exact date when he went back to Siam is unknown, however already in 1915; he organized a research expedition there. In Siam he was named a university professor and a governmental councillor, according to published reports (Lupša 1925). The next information that is known about him, is that he was a war prisoner in Ahmednagar in India in April of 1919, from where he came back home in 1920 (Lupša 1919). His life ends at the beginning of 1945 .

In Siam he organized two expeditions, scientific caravans as he called them. The first one visited the extreme northern parts of Siam and the adjacent parts of Burma and Laos; it started in April 1915 from the town of Lampang in the Northern Thailand. The second one started in late December of the same year from the town Rahang, modern Tak on the river Me Ping. The aim of the scientific caravans was to study flora and fauna of the area, 
the life of various tribes and to collect ethnological material. For a transport he used small Siam horses, oxen (up to 30), elephants, bamboo rafts, and porters. During the expedition he took photos and draw many motifs from nature. He sent photos to Karol Grossmann, the first Slovenian film-maker, who used them for the presentations at the Reading Society at Ljutomer.

The 1916 expedition travelled to the west of Rahang into the mountains along the Siam - Burma border in the territory of the Karen Nation, the ancient Kingdom of Sukhothai. During the climb up the Doi Kam Ho Mountain Ferdo Lupša observed rough limestone crests, pillars, isolated peaks, sinking streams, and at the foot of limestone walls numerous hollows and underground galleries. The expedition established a camp in a limestone canyon in the middle of the jungle. Two Karen men passed by the camp carrying killed black bear on a pole. They told them that when pursuing the bear, they passed a cave entrance. According to them, the cave has to be a dwelling of a dangerous demon Soe Phi Lok. Lupša with difficulties persuaded one of the men to show him the cave the next morning. The following description is the translation of essential parts from his book "In the jungle of White Elephant" (1930):

"The next morning, I and a group of Lao tribesmen, reached the entrance [of the cave], just large enough for a man to crawl in. The gallery was long, getting more and more narrow, winding down to about $40 \mathrm{~m}$. With charcoal we made signs on walls to find the way out. At the end of the passage a wonderful chamber full of stalagmites and stalactites was revealed. To better see it we lit torches. It was round, having $25 \mathrm{~m}$ of diameter and over $30 \mathrm{~m}$ high and we named it Prasat Phra Kan (Sovereign Time from Siamese legends). By gently inclined gallery we reached another, much bigger chamber: $38 \mathrm{~m}$ large, $84 \mathrm{~m}$ long. The ceiling was not visible in the light of two torches. We gave it the name Prasat Soe Phi (Legendary Tiger). Among many stalagmites there was a giant about

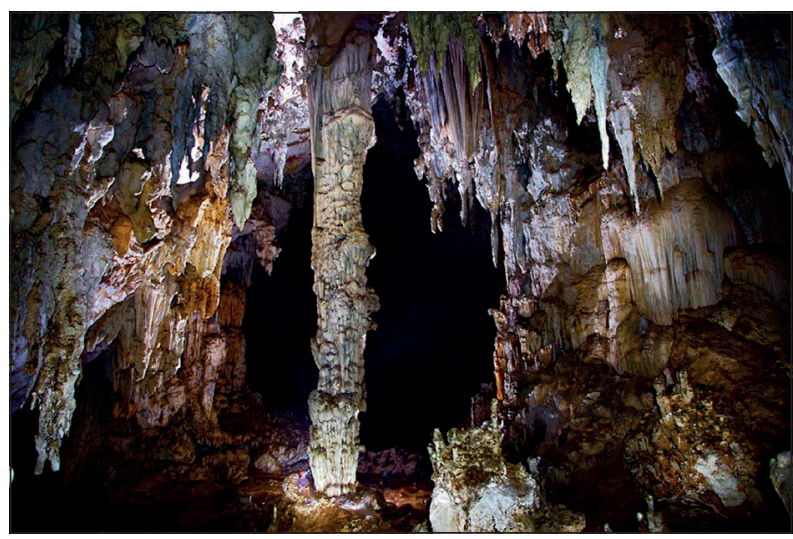

The cave Tham-Lum-Khao-Aka from Western Thailand may resemble to Lupša's Vang Narasinh Cave?
$20 \mathrm{~m}$ high, which can be compared to that from the cave of Dargilan (France). It got the name of Khung Chang, and a smaller one in the middle we called Khun Nandi. On the floor, crushed flowstone was covered by new crystal flowstone.

From the Prasat Soe Phi chamber there were two galleries, one leading towards SW, the other one towards SE. Following the SW passage, we reached three smaller chambers connected to each other by short galleries. In the last one there were pieces of crushed spelothems at least one meter and a half in diameter. From here a passage leads steeply upwards to the mountain crest, probably leading to, for us inaccessible galleries and chambers above. From the middle of the last three chambers a gallery leads down to a deep dark shaft from where it was possible to hear the noise of water. According to the stone thrown down it was at least $50 \mathrm{~m}$ deep.

We returned to Prasat Soe Phi chamber and continued by the SE passage about $50 \mathrm{~m}$ forward to discover a new $30 \mathrm{~m}$ long and $10 \mathrm{~m}$ large chamber which we named Prasat Noi (Small Chamber). From this chamber a short gallery decorated by nice speleothems continued and ended again by a deep shaft. From its edge one could hear murmuring water. Having neither equipment nor time we were unable to examine the other parts of these underground galleries. I am sure that we have seen just a small part of this majestic underground labyrinth we found by chance. Cave as a whole we named Vang Narasinha - Lion's Palace meaning the lion of the Vishnu's fourth incarnation."

The next stage of the expedition followed the caravan way from Umphang to Kamphaeng Phet in the Western Thailand, along the border with Burma. Because of difficult and demanding road, they exchanged the elephants at Umphang. The journey followed the stream of Huey Umphang and the way was often steep and stony, full of sharp rocks, over rough karst surface. After leaving the village Ban Dibloe they entered a long and narrow gorge.

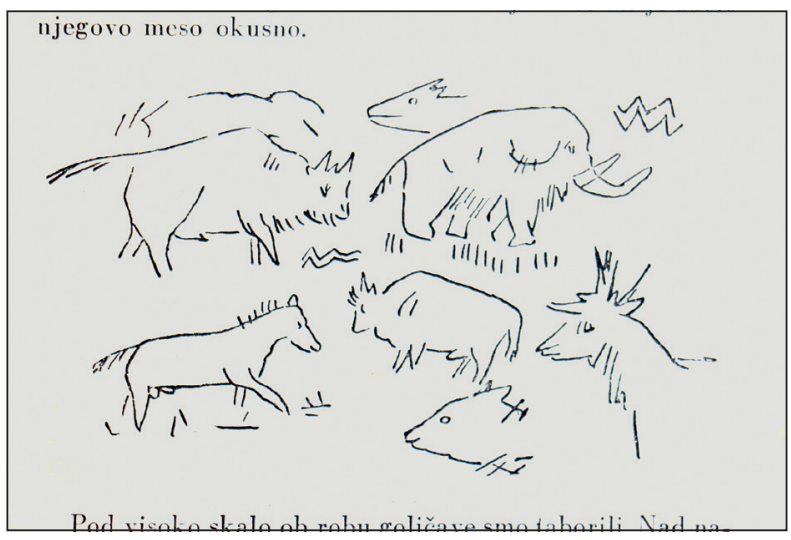

Lupša's copy of wall engravings in the cave above the village of Ban Dibloe (Lupša 1930). 
They set up the camp under a high rock with a cave at its foot. The walls of the cave were decorated with unusual pictures. Taking into account the natural state of the cave, Lupša evaluated the age of the pictures to be about 4,000 years. The cave wall contained representations of a horse, a giant gaur (Bos gaurus), a buffalo, an elephant, and heads of a tiger and a sort of a bear (see picture). In this part of Thailand, where Lupša observed and copied cave engravings, that is in regions of Kanchanaburi, Ubon Ratchathani, Nakhon Si Thammarat, and Lopburi, stone tools have been widely found. Prehistoric cave paintings have also been found in these regions, dating back 10,000 years (Wikipedia 2021).

Lupša and his team visited Vang Narasinha and the cave with prehistorical gravures early in the year 1916. According to his publications, it is clear that his group was the first who dared to enter Vang Narashina. The cave was not known to the local Karen people and it did not have a name before Lupša gave it. From vague location mentioned in Lupšas book it is impossible to determine if the cave was later entered and explored by any modern speleologists. Actually (October 2019), there are over 4,600 registered caves in Thailand (Thailandcaves 2021a) and their bibliography consists of 2,412 units. As one can find out from the register of caves, there is none with a name Vang Narasinha; this being quite understandable. From the bibliography (Thailandcaves 2021b) one can see that caves in Thailand have been mentioned quite early. The earliest document is "A Trang cave text of $1614 \mathrm{AD} «$ (Diller 1998). There are 40 publications issued before the year 1916, the oldest among them from 1717 (Moll 1717), describing a religious cave. Among these 40 publications only 7 have the word "cave" in the title. In any case, the majority of them are reports of travellers or men involved in railway construction and caves, if mentioned at all, are only of minor importance.

To conclude, one can say that Lupšass exploration and description of Vang Narasinh Cave and another cave's presumable Palaeolithic cave engravings is one of the earliest real cave explorations, executed in Western Thailand by an Austrian citizen, while in those times most of them, who mentioned caves in Thailand, where British. Lupša was the first but not the only Slovenian exploring caves in Thailand. Recently, among various speleologists working in Thailand, there are also some Slovenians.

\section{REFERENCES:}

Anonymous, 1893: Notes sur Lung-Prabang.- Revue Indo-Chinoise Illustrée, 5, 78-117.

Anonymous, 1895: An Englishman's Siamese Journal 1890-1893. Report of a Survey in Siam.- Siam Media International Books (reprinted), pp. 276, Bangkok.

Diller, A., 1998: A Trang cave text of 1614 AD.- Journal of the Siam Society, 86 (1/2), 232-234.

Lupša, F., 1904a: Dopisi, Klong-Sib-Pat, 1. maja 1904, Glas iz Siama.- Domovina, 48, 4.

Lupša, F., 1904b: Klong-Ji-Sib-Soung, 25. maja 1904, Glas iz Siama.- Domovina, 55, 1.

Lupša, F., 1906: Dopisi, Kraljevi inžener v Siamu.- Domovina, 67, 2.

Lupša, F., 1919: Dnevne novice, Pomoč našim vojnim ujetnikom. -Mariborski delavec, 169, 3.

Lupša, F. 1925: Iz Maribora, Potovanje po Siamu.- Slovenski narod, 120, 3.
Lupša, F., 1930: V džunglah belega slona. -Vodnikova družba, pp. 114, Ljubljana.

Moll, H., 1717: The east part of India and India beyond the River Ganges (map).- London.

Thailandcaves, 2021a: Cave Survey Data.-[Online] Available from: https://www.thailandcaves.shepton.org. uk/cave-survey-data [Accessed May 11th, 2021]

Thailandcaves, 2021b: Cave and karst bibliography.[Online] Available from: https://www.thailandcaves.shepton.org.uk/cave-bibliography [Accessed May 11th, 2021]

Wikipedia 2021: Prehistoric Thailand.- [Online] Available from: https://en.wikipedia.org/wiki/Prehistoric_Thailand [Accessed May 11th, 2021] 